\title{
KANDIDATSPECIALER OG PH.D.-AFHANDLINGER OM SKOLE OG UDDANNELSE
}

Redaktionen bringer her en fortegnelse over specialer og ph.d.-afhandlinger fra både København og Århus, der på forskellig vis beskæftiger sig med uddannelse og skole. Vi kan på ingen måde garantere, at listen er komplet, men hører gerne om mangler, da vi eventuelt senere kan bringe en mere komplet liste på vores hjemmeside.

\section{Kandidatspecialer Institut for Antropologi, Københavns Universitet (2001-2010)}

\section{Louise V. Johansen}

De måske oplyste. Diskurser om republikanisme, race og social klasse og deres virkning inden for grundskolen i Frankrig. 2001.

Maren Ottar Jensen

En intim sag. En antropologisk analyse af studenterpolitisk praksis på et tyrkisk universitetscampus. 2001.

Ellen Bangsbo Andersen

Tibetanske klostre i eksil. En undersøgelse omkring betydningen af monastisk og sekulær uddannelse for munke i Boudhanath, Nepal, belyst ud fra en lokal og global kontekst. 2001.

Sisse Birgitte Priergaard Hansen

Børn, ligeværd og kulturel forskellighed. Et antropologisk studie af tosprogede og danske børns betydningsdannelse af forholdet mellem ligeværd og kulturel forskellighed $i$ en dansk folkeskole. 2001 .

Jakob K. Hansen

Are Black Teachers Lazy? An Anthropological Perspective on South African Education Reform. 2002.

Marianne Iversen

Hier Lieft es Alles live. Om multikulturel praksis og diskursiv brug af kulturbegreber på den tysktyrkiske europaskole i Kreuzberg, Berlin. 2002.

Birgitte Feiring

At lære at tænke rigtigt. Skoler og selvmord blandt aguaruna og huambisa. 2003.

Mia Lange

Nothing Personal. A Study of Social and Spatial Practices of Distancing in a UK Secondary School. 2003.

Jette Cabo

Drømmepiger i dagslys. Et antropologisk studie af magtforhold blandt en gruppe catalanske skolepiger af andalusisk oprindelse belyst ud fra drømmenarrativer og narrativer om det sociale liv. 2003.

Vibe Sanning

Man kan ikke se klasse for bare grupper. Et antropologisk studie af social gruppedannelse og kategorisering blandt unge på københavnske handelsgymnasier. 2004. 
Clara Jørgensen

Fri og lige uddannelse? En antropologisk diskussion af betalinger i en gratis nicaraguansk grundskole og deres konsekvens for frafald. 2004.

Monika Sørensen

På jagt efter respekt i skolen. Venskaber, konflikter og identificeringer i en folkeskole i en flerkulturel bydel. 2004.

Nina Jantzen

At lære at lære. Et studie af læringsrum og elevidentitet i grundskoler i New Zealand. 2005.

Sara Lei Jacobsen

Uddannet og anstændig. Kvindelige universitetsstuderende i Damaskus. 2005.

Pia Kock

Børn skal lære at bruge deres krop. Samfundstendenser og institutionel civilisering i indskolingen i en dansk folkeskole. 2005.

Heidi Laustsen

Vi foretrækker at tale med nogen, der tænker ligesom os selv. En antropologisk analyse af kategoriseringsprocesser og identitetsforhandlinger blandt minoritetsdanske kursister på et dansk sprogcenter. 2006.

Berthe Kranich

Lad os snakke sammen. En antropologisk analyse af følelseskultur i folkeskolen. 2006.

Karen Waltorp Sørensen

Uddannelse, dårlig dannelse, drømme og dagligdag. At være ung i den „farvede“ township Manenberg i Sydafrika. 2007.

Mette Juel Madsen

Race towards Transformation. Ethnographic Explorations on Schooling and Social Change in South Africa. 2008.

Marie L. Ryberg

Den moderne skole i forandring: Lærere og viden i Brcko, Bosnien-Hercegovina. 2008.

Gry Thorsen

„Koran, jeg hader piger, mand!“ En etnografi om komplekse konstruktioner af social identitet blandt børn på en arabisk friskole i Danmark. 2008.

Line Hillersdal

„The Education Path“. Professionel tilblivelse og politisk agens blandt kommende og yngre lærere i Sri Lanka. 2009.

Anne Katrine Kamstrup

„Hvis du bare arbejder hårdt nok ..." En antropologisk analyse af forestillinger om succes blandt latinamerikanske migranter på en amerikansk middle school. 2010.

\section{Ph.d.-afhandlinger \\ Institut for Antropologi, Københavns Universitet (2001-2010)}

Lotte Meinert

The Quest for a Good Life. Health and Education among Children in Eastern Uganda. 2001. 


\section{Karen Valentin}

The Paradox of Schooling: The Possibilities of Formal Education for Squatter Families in Kathmandu, Nepal. 2001.

Sally Anderson

Civilizing Children: Children's Sport and Civil Sociality in Copenhagen, Denmark. 2002.

\section{Kandidatspecialer Afdeling for Antropologi og Etnografi, Århus Universitet (2000-2010)}

Mathilde Carlsen

Ideen om nationen i den italienske skolepolitik. En analyse af ideen om nationen i de nationale undervisningsplaner i Italien. 2000.

Marianne Jespersen

På lige fod? En antropologisk undersøgelse af ikke-vestlige kvindelige efterkommeres relationer til uddannelsessystemet og arbejdsmarkedet. 2003.

Miguel Romero Mikkelsen

Børn, fællesskab og integration. En antropologisk undersøgelse af børns ven- og fællesskaber i en dansk folkeskoleklasse. (sammen med kandidatspeciale). 2003.

Marianne Schmidt Nikolajsen

Køn, identitet og skoleliv. En antropologisk undersøgelse af skabelse af kønsidentitet blandt 1215-årige elever i en dansk folkeskole. 2003.

Karin Daugaard Hansen

Etniske minoritetspiger - etniske uddannelsespraksisser? En antropologisk analyse af unge etniske minoritetspigers uddannelsespraksis og frafald på erhvervsuddannelser med særlig fokus på betydningen af etnisk identitet og baggrund. 2007.

Rikke Elisabeth Frederiksen

På vej mod fremtiden. Albanske gymnasieelevers daglige og fremtidige uddannelse. 2008.

Dorrit Jensen

„Verdensskoler“. Et kritisk studie af international skoling og kosmopolitisk borgerskab. 2008.

Linda Johnsen

„How can we develop?“ En antropologisk diskussion af ungdom, udvikling og uddannelse i Nyabyeya, Uganda. 2008.

Simon Westergaard Lex

Mission uddannelse: vejen til et ideologisk fællesskab. En antropologisk analyse af de sociale uddannelsesmissioner i Venezuela. 2008.

Sara Seerup Laursen

I en verden af usikkerhed. Et antropologisk studie af betydningen af hemmeligholdelse blandt universitetsstuderende i Rwanda efter folkemordet. 2009.

Lotte Sandberg Kjær

„Vi må prøve at finde os selv.“ Et antropologisk perspektiv på unges dilemma i Gymnasiet i Grønland. 2009.

Anne Jørgensen

„Det handler jo om hans kultur ...“ En antropologisk undersøgelse af, hvordan fokusering på „det anderledes“ kan modarbejde chancelighed for eleverne på en „multikulturel skole“. 2009. 
Mette Kølner Jørgensen

„I Tanzania siger vi, at udvikling er en lang rejse, som starter med uddannelse.“ Det moderne set gennem kønnede oplevelser af uddannelse i Sengerema. 2009.

Tue Thinggaard

Tyrkiske indvandrere i folkeskolen. Set ud fra Bourdieu og teorien om segmenteret assimilation. 2010. 